\title{
Human Brain Serotonin Synthesis Capacity Measured In Vivo with $\alpha$-[C-11]Methyl-L-Tryptophan
}

\author{
DIANE C. CHUGANI, ,, $2 *$ OTTO MUZIK, ${ }^{2}$ PULAK CHAKRABORTY, \\ THOMAS MANGNE R, ${ }^{2}$ AND HARRY T. CHUGANI $1,2,3$ \\ ${ }^{1}$ Department of Pediatrics, Children's Hospital of Michigan, WayneStateUniversity School of Medicine, \\ Detroit, Michigan \\ 2Department of Radiology, Children's Hospital of Michigan, WayneStateUniversity School of Medicine, \\ Detroit, Michigan \\ ${ }^{3}$ Department of Neurology, Children's Hospital of Michigan, WayneStateUniversity School of Medicine, \\ Detroit, Michigan
}

\begin{abstract}
KEY WORDS Serotonin; tryptophan; $\alpha$-methyl-tryptophan; positron emission tomography; Patlak analysis
\end{abstract}

\begin{abstract}
Local cerebral serotonin synthesis capacity was measured with $\alpha$-[C11]methyl-L-tryptophan ([C-11]AMT) in normal adult human brain ( $n=10$; five males, five females; age range, 18-38 years, mean 28.3 years) by using positron emission tomography (PET). [C-11]AMT is an analog of tryptophan, the precursor for serotonin synthesis, and is converted to $\alpha$-[C-11]methyl-serotonin ([C-11]AM-5HT), which is trapped in serotonergic neurons because [C-11]AM-5HT is not degraded by monoamine oxidase. Kinetic analysis of [C-11] activity in brain after injection of [C-11]AMT confirmed the presence of a compartment with unidirectional uptake that represented approximately $40 \%$ of the activity in the brain at $50 \mathrm{~min}$ after tracer administration. The undirectional rate constant $\mathrm{K}$, which represents the uptake of [C-11]AMT from the plasma to brain tissue followed by the synthesis and physiologic trapping of [C-11]AM$5 \mathrm{HT}$, was calculated using the Patlak graphic approach on a pixel-by-pixel basis, thus creating parametric images. The rank order of $\mathrm{K}$ values for different brain regions corresponded well to the regional concentrations of serotonin in human brain $(\mathrm{P}<.0001)$. High serotonin synthesis capacity values were measured in putamen, caudate, thalamus, and hippocampus. Among cortical regi ons, the highest values were measured in the rectal gyrus of the inferior frontal lobe, followed by transverse temporal gyrus; anterior and posterior cingulate gyrus; middle, superior, and inferior temporal gyri; parietal cortex; occipital cortex, in descending order. Values in women were $10-20 \%$ higher $(\mathrm{P}<.05, \mathrm{MANOVA})$ throughout the brain than those measured in men. Differences in the serotonin synthesis capacity between men and women measured in this study may reflect gender differences of importance to both normal and pathologic behavior. This study demonstrates the suitability of [C-11]AMT as a tracer for PET scanning of serotonin synthesis capacity in human brain and provides normal adult values for future comparison with patient groups. Synapse 28:33-43, 1998. $\odot 1998$ Wiley-Liss, Inc.
\end{abstract}

\section{INTRODUCTION}

Serotonin (5-hydroxytryptamine, $5 \mathrm{HT}$ ) is phylogenetically the oldest of the biogenic amine neurotransmitters. This may account for the finding that more receptors have evolved for this aminethan for any other known neurotransmitter (Peroutka, 1994). Pharmacologic and molecular genetic evidence have demonstrated evolution of at least three classes of $5 \mathrm{HT}$ receptors (5HT1,5HT2, 5HT3) and possibly up to seven classes based on structural and functional characteristics (for classification, see Hoyer et al., 1994), with the members of these families totaling at least 14 distinct molecular entities. The study of these receptors both in vitro and in vivo has been hindered by the lack of specific pharmacologic agents. Indeed, much of the pharmacologic classification of these receptors has relied on ligand and multiple displacing agents to define the location and function of specific 5HT receptors.

\footnotetext{
*Correspondence to: Diane C. Chugani, Ph.D., Children's Hospital of Michigan PET Center, 3901 Beaubien BIvd., Detroit, MI 48201

Received 5 F ebruary 1997; accepted 19April 1997
} 
In vivo imaging using probes aimed at investigating serotonergi c function has been an area of great interest because serotonergic neurotransmission is postulated to provide a tonic modulatory role in brain development and is important in such diverse functions as feeding, sleep, sexual behavior, and mood (for review, seeJ acobs and Azmitia, 1992). In addition, there is evidence that abnormalities of serotonergic neurotransmission are associated with several neurologic and psychiatric disorders, including autism, migraine, sleep disorders, depression, movement disorders, and epilepsy (for reviews, see Murphy, 1990; Roth, 1994).

$\alpha$-[C-11]M ethyl-L-tryptophan ([C-11]AMT), which has been devel oped as a tracer for serotonin synthesis with positron emission tomography (PET) (Diksic et al., 1991), is an analog of tryptophan, the precursor for serotonin synthesis. After the administration of label ed or unlabeled $\alpha$-methyl-L-tryptophan (AMT) in rats, conversion to $\alpha$-methyl-serotonin (AM-5HT) in brain has been demonstrated by high-pressure liquid chromatography (HPLC) (Diksic et al., 1990; Missala and Sourkes, 1988). [H-3] $\alpha$-methyl-serotonin ([H-3]AM$5 \mathrm{HT}$ ) synthesized in brain was local ized to serotonergic neurons and nervetermi nals by combined autoradiography and tryptophan hydroxylase immunocytochemistry at the el ectron microscopic level (Cohen et al., 1995). Furthermore, [H-3]AM-5HT present in nerve terminals could be rel eased by potassium-induced depolarization, suggesting that this tracer is stored with the rel easable pool of serotonin (Cohen et al., 1995). BecauseAM-5HT, unlike serotonin, is not a substrate for the degradative enzyme monoamine oxidase (Missala and Sourkes, 1988), accumulation of AM-5HT occurs in serotonergic terminals. In addition, AMT, unlike tryptophan, is not incorporated into protein in significant amounts (Diksic et al., 1990; Madras and Sourkes, 1965). These properties simplify the kinetic modeling of AMT, making it a suitable tracer substance for the study of serotonin synthesis in vivo. We now report the measurement of local cerebral serotonin synthesis capacity with [C11]AMT in normal adult human brain by using PET.

\section{METHODS Theory}

Studies of [C-14]AMT in rat (Diksic et al., 1990) and [C-11]AMT in dog (Diksic et al., 1991) have demonstrated that the kinetic behavior of the tracer AMT can be described by a three-compartment model using first-order rate constants (schematically represented in Fig. 1). The inflow rate constant $K_{1}(\mathrm{ml} / \mathrm{g} / \mathrm{min})$ and the outflow rate constant $k_{2}(1 / \mathrm{min})$ both describe the exchange of [C-11]AMT between vascular space and the cell cytoplasm (transport across the blood-brain barrier, the interstitial space, and the cell membrane). Approximately $20 \%$ of AMT in plasma is bound to albumin, whereas $90 \%$ of plasma tryptophan is bound (Shoaf and

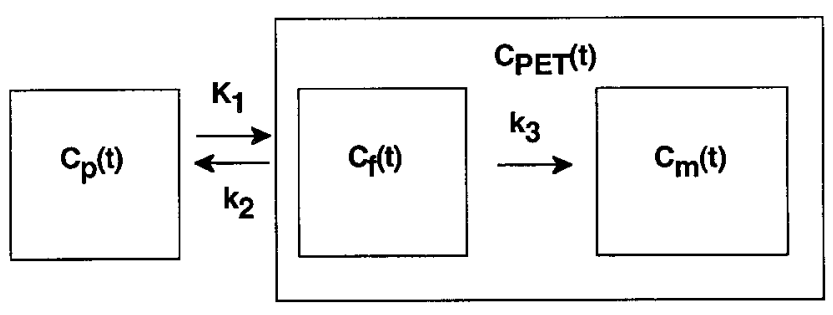

Fig. 1. Three compartment model for [C-11]AMT kinetics in brain. The inflow rate constant $K_{1}$ and the outflow rate constant $k_{2}$ both describe the exchange of [C-11]AMT between vascular space $\left(\mathrm{C}_{\mathrm{p}}\right)$ and the cell cytoplasm $\left(C_{f}\right)$. Once present in $C_{f}$, [C-11]AMT is converted to [C-11]AM-5HT $\left(\mathrm{C}_{\mathrm{m}}\right)$ by means of an irreversible, two-step enzymatic process, which is characterized by the rate constant $k_{3}$. The PET tissue signal is denoted as $C_{P E T}$ and represents a combination of both the $C_{f}$ and $C_{m}$ signals.

Schmall, 1996). AMT competes with tryptophan and other large neutral amino acids for transport across the blood-brain barrier (Diksic et al., 1990). Once present in the cytoplasm of serotonergic neurons $\left(\mathrm{C}_{\mathrm{f}}\right)$, [C-11]AMT is converted to [C-11]AM-5HT $\left(\mathrm{C}_{\mathrm{m}}\right)$ by means of an irreversible, two-step enzymatic process, which is characterized by the rate constant $k_{3}(1 / \mathrm{min})$. The ratelimiting step of this process is the irreversible hydroxylation of [C-11]AMT to[C-11]AM-5-hydroxy-tryptophan mediated by tryptophan hydroxylase. The solution for the set of differential equations describing the threecompartment model shown in Figure 1 has been previously reported (Sokol off et al., 1977). Rel iable estimates of the individual rate constants $\mathrm{K}_{1}, \mathrm{k}_{2}$, and $\mathrm{k}_{3}$ for [C-11]AMT by using this method, however, could only be obtained for large regions of the brain due to the low identifiability of the model, which is caused by the low count statistics originating from the low single-pass extraction fraction of the tracer (approximately $2 \%$ ) and the short physical half-life of [C-11] (Muzik et al., 1997).

The graphic approach described by Patlak et al. (1983) is an alternative method of analysis that allows the determination of the undirectional uptake rate constant $\mathrm{K}$, which represents the uptake of [C-11]AMT from the plasma to brain tissue fol lowed by the synthesis and physiologic trapping of [C-11]AM-5HT. This approach assumes that the system to be analyzed consists of a homogenous tissue region with any number of compartments that communicate reversibly with the blood. In addition, there must be at least one compartment that the tracer enters in an irreversible manner. As discussed by Patlak et al. (1983), at long enough times after admi nistration of tracer $\left(t>t^{*}\right)$, the amount of tracer in the reversible compartments will be in effective steady state, with plasma yielding a linear function

$$
\frac{C_{P E T}\left(t_{i}\right)}{C_{p}\left(t_{i}\right)}=K \frac{\int_{0}^{t_{i}} C_{p}(u) d u}{C_{p}\left(t_{i}\right)}+b \quad t_{i}>t^{*}
$$


where $C_{P E T}(t)$ is the measured [C-11] tissue concentration at midscan time $t_{i}, C_{p}(t)$ is the concentration of [C-11]AMT in plasma at time $\mathrm{t}, \mathrm{K}$ is the rate constant for unidirectional uptake of [C-11]AMT from plasma to tissue during steady state, and $b$ is a positive constant equal to the equilibrium space of the exchangeable compartments. Hence, if $C_{P E T}(t) / C_{p}(t)$ is plotted against $\theta\left[={ }_{0} \int{ }^{t} C_{p}(u) d u / C_{p}(t)\right]$, then during steady state $(t>t *)$, the curve should be a straight line with a positive intercept and a slope equal to the rate constant $\mathrm{K}$ for unidirectional uptake of [C-11]AMT from plasma to tissue. The units of the rate constant $\mathrm{K}$ are $\mathrm{ml} / \mathrm{g} / \mathrm{min}$.

Finally, the standardized uptake value (SUV) method for semiquantitative analysis of tracer accumulation (Kenney et al., 1941; Woodard et al., 1975) can be applied to the data. TheSUV is a method widely used to assess metabolic activity in tumors using [F-18]fluorodeoxyglucose (Gupta et al., 1992; Strauss and Conti, 1991), because absolute values of the metabolic rate are difficult to obtain due to several unknown variables in tumors, including the lumped constant (LC), a factor accounting for the differences between the kinetics of the tracer and the natural substrate. Likewise, the LC for [C-11]AMT in humans is unknown, and there are differences in LC between the species for which it is known. The LC was measured as 0.43 in rats (Vanier et al., 1995) and 0.18 in rhesus monkeys (Shoaf and Schmall, 1996). In addition, there is considerable controversy in the literature regarding the fraction of tryptophan in blood available for transport into the brain, which is the other factor necessary for calculation of the absolute serotonin synthesis rate. The two main factors that affect the availability of tryptophan to the brain are the free plasma tryptophan concentration and the plasma concentration of other large neutral amino acids that compete with tryptophan for transport across the blood-brain barrier (Bloxam et al., 1980; F ernstrom and Wurtman, 1972; Fernstrom et al., 1973). The free tryptophan concentration is determined by the degree of binding to plasma albumin (Bloxam and Curzon, 1978; Gessa and Tagliamonte, 1974; K nott and Curzon, 1972). However, there is al so evidence that tryptophan bound to albumin is "stripped" from albumin as the blood circulates through the brain (Pardridge, 1979; Pardridge and Fierer, 1990; Yuwiler et al., 1977). Furthermore, there is historical evidence to indicate that serum total tryptophan is a better indicator of the amount available for brain entry rather than free tryptophan (Madras et al., 1973, 1974).

The SUV in different regions of the brain is equal to the sum of the precusor [C-11]AMT and the metabolic product [C-11]AM-5HT synthesized in these regions, independent of the various physi ologic processes affecting the serotonin synthesis rate described above. The SUV calculation relates tracer concentration in tissue to the dose injected and the subject's mass (Kenney et
TABLE I. Radiation dosecalculation (based on the MIRDOSE program (IBM PC version 3.0-N ovember '94) provided by ORISE)

\begin{tabular}{|c|c|c|c|}
\hline Organ & $\mathrm{mrem} / \mathrm{mCi}$ & Organ & $\mathrm{mrem} / \mathrm{mCi}$ \\
\hline Adrenals & 13.0 & Ovaries & 17.6 \\
\hline Brain & 8.8 & Pancreas & 13.0 \\
\hline Breasts & 8.5 & Red marrow & 14.5 \\
\hline Gallbladder wall & 13.2 & Bone surface & 12.6 \\
\hline \multirow{2}{*}{$\begin{array}{l}\text { Lower large intestine } \\
\text { wall }\end{array}$} & & Skin & 8.0 \\
\hline & 11.8 & Spleen & 15.9 \\
\hline Small intestine & 20.1 & Testes & 9.5 \\
\hline Stomach & 14.3 & Thymus & 10.0 \\
\hline \multicolumn{2}{|l|}{ Upper large intestine } & Thyroid & 9.7 \\
\hline wall & 12.7 & Urinary bladder wall & 27.0 \\
\hline Heart wall & 14.4 & Uterus & 12.7 \\
\hline Kidney & 91.4 & TOTAL BODY & 10.4 \\
\hline Liver & 17.6 & \multirow{2}{*}{$\begin{array}{l}\text { Effective dose equiv- } \\
\text { alent }\end{array}$} & \\
\hline Lungs & 13.3 & & 20.0 \\
\hline Muscle & 9.6 & & \\
\hline \multicolumn{3}{|c|}{$\begin{array}{l}\text { Administered dose to human subjects: } \\
\text { Total dose to } 70-\mathrm{kg} \text { human: } \\
\text { Dose to critical organ (kidney): } \\
\text { Effective dose equivalent: }\end{array}$} & $\begin{array}{l}.4 \mathrm{mCi} / \mathrm{kg} \\
8-\mathrm{mCi} \text { injection } \\
.56 \mathrm{rem} \\
.56 \mathrm{rem}\end{array}$ \\
\hline
\end{tabular}

al., 1941; Woodard et al., 1975) (SUV = tissue concentration in regions of interest $(\mathrm{ROI})(\mu \mathrm{Ci} / \mathrm{ml}) /$ injected dose per weight $(\mathrm{mCi} / \mathrm{kg})$.

\section{Radiation dosimetry}

The organ distribution $(\mu \mathrm{Ci} / \mathrm{g})$ of [C-11]AMT, normalized to injected activity and body weight, was determined in four rats (180-240 g) at $1 \mathrm{~h}$ after intravenous injection of approximately $2 \mathrm{mCi}$ of the tracer. Human organ activity and resi dence times were estimated from the rat data by using organ weights from IRCP Publication 53 (1988) and by assuming a total human body weight of $70 \mathrm{~kg}$. Final values of radiation dose were calculated by using the residence time estimates and the MIRDOSE program (Oak Ridge Institute for Science and Education, Oak Ridge, TN, IBM PC Version 3.0, November 1994) (Table I). For [C-11]AMT, the critical organs are the kidneys. The maximum allowable dose under Code of Federal Regulation guidelines (resulting in a radiation exposure of $5 \mathrm{rem}$ in one session to the kidneys) is $55 \mathrm{mCi}$.

\section{Subjects}

Human subjects ( $n=10$, five males, five females; age range, 18-38 years; mean age, 28.3 years) were recruited by advertisement and underwent a screening interview to ensure the absence of mental or neurologic disorders, and the use of centrally active pharmacologic agents. Studies were performed in compliance with the regulations of the Wayne State University Human Investigation and Radioactive Drug Research Committees, and informed consent was obtained before all studies.

\section{PET protocol}

PET studies with the tracer [C-11]AMT were performed by using the CTI/Siemens EXACT/HR whole 
body positron tomograph (Knoxville, TN). This scanner has a 15-cm field of view and generates 47 image planes with a slice thickness of $3.125 \mathrm{~mm}$. The reconstructed image in-plane resolution obtained is $5.5 \pm 0.35 \mathrm{~mm}$ at full-width-at-half-maximum (FWHM) and $6.0 \pm 0.49$ $\mathrm{mm}$ in the axial direction (reconstruction parameters: Hanning filter with 0.20 cycles/pixel cutoff frequency). Calculated attenuation correction was performed on all images by using the technique described by Bergström et al. (1982). [C-11]AMT was produced in 50-65\% radi ochemical yield (decay corrected from [C-11]M el ) as described by Chakraborty et al. (1996). Radiochemical purity, determined by radio-HPLC, was greater than $98 \%$. Specific activity of [C-11]AMT at time of injection ranged from 500 to $1,000 \mathrm{Ci} / \mathrm{mmol}$. Theaverage injected dose to the subjects was $30 \mathrm{mCi}(23-38 \mathrm{mCi})$ and contained $9 \mu \mathrm{g}(3-16 \mu \mathrm{g})$ of AMT and $330 \mu \mathrm{g}(100-535$ $\mu \mathrm{g})$ of L-tryptophan.

Subjects were fasted for $12 \mathrm{~h}$ before the PET procedure to obtain stable plasma tryptophan levels during the course of the study, as well as to minimize the effects of insulin status, free fatty acid levels, and diet on plasma protein binding of tryptophan and AMT. A commercial SIEMENS/CTI head holder was used in combination with Velcro strips to immobilize the patient's head during the scan. A venous catheter was established for tracer injection, and an arterial catheter was placed in a percutaneous radial artery for collection of 28 timed arterial blood samples $(0.5 \mathrm{ml} / \mathrm{sample}$, sequence: $18 \times 10 \mathrm{sec}, 2 \times 1 \mathrm{~min}, 2 \times 2.5 \mathrm{~min}, 2 \times 5$ $\mathrm{min}, 4 \times 10 \mathrm{~min})$. Radioactivity in plasma was measured by using a Cobra II gamma counter (Hewlett Packard, Downers Grove, IL) which was calibrated with the PET scanner. Metabolite-correction of the plasma is unnecessary because metabolites [AM-5HT (Minderaa et al., 1987), incorporation in plasma protein (Diksic et al., 1991), and metabolites of the kynurenine pathway (Madras and Sourkes, 1965; Sourkes, 1971)] constitute less than $2 \%$ of the activity in plasma. Plasma tryptophan concentrations (at zero, 10, 30, and $60 \mathrm{~min}$ ) were measured by HPLC as described by Krstulovic et al. (1979). Repeated measurements of plasma tryptophan for each subject demonstrated a constant value for plasma tryptophan for the duration of the study and showed little variability among patients (range, 28-38 $\mu \mathrm{m}$; mean, $32.4 \mu \mathrm{M} \pm 4.2 \mathrm{SD}$; $\mathrm{n}=10)$ and no statistically significant difference between men (range, 26-37 $\mu \mathrm{M}$; mean, $31.6 \mu \mathrm{M}+4.0 \mathrm{SD}$; $\mathrm{n}=5$ ) and women (range, 28-38; mean, $33.6 \mu \mathrm{m}+4.1$ $\mathrm{SD} ; \mathrm{n}=5)$. The tracer [C-11]AMT $(0.4 \mathrm{mCi} / \mathrm{kg}, 38 \mathrm{mCi}$ maximum) was injected intravenously as a slow bolus over 2 min by using a Harvard pump. Beginning at the time of injection, a 60-min dynamic PET scan of the brain was performed (sequence: $4 \times 30 \mathrm{sec}, 3 \times 1 \mathrm{~min}$, $2 \times 2.5 \mathrm{~min}, 10 \times 5 \mathrm{~min})$. Due to limited experience with [C-11]AMT in humans, physiologic parameters (heart rate, blood pressure, pulse oximetry, blood gases) were measured periodically during the study. No adverse reaction to infusion of [C-11]AMT was observed in any of the subjects.

\section{Data processing and analysis}

To allow for efficient analysis of PET data, a software package written in IDL v.4.0.1 (Research Systems Inc., Boulder, CO) and running under SunOS 4.1.3/Openwindows 3.0 using a network of SUN Sparc IPX/Sparc 5 workstations (SUN Microsystems I nc., M ountain View, CA) was developed. The software environment includes motion correction of the dynamic frame sequence, nonlinear estimation of rate constants, and the estimation of the unidirectional rate constant $\mathrm{K}$ according to Equation 1 on a pixel-by-pixel basis.

\section{Regions of interest}

Brain ROIs were drawn on PET images calibrated to $\mu \mathrm{Ci} / \mathrm{ml}$, representing the retention of [C-11]AMT from 30 to $55 \mathrm{~min}$, by an expert observer who defined ROIs based on comparison of image activity distribution with a Tallairach brain atlas. The time 30-55 min for activity summation was chosen because it represents the best contrast between activity in tissue and blood pool. Because all subjects received a standardized dose based on their weight $(0.4 \mathrm{mCi} / \mathrm{kg})$, calibrated images directly depict the SUV value. ROIs were drawn in all planes, showing a particular structure, and the average concentration for individual structures was determined by weighting the appropriate region concentration determined in each plane by the size of the region in the plane. These ROIs were also subsequently copied to parametric images representing the unidirectional uptake rate constant $\mathrm{K}$ as described below.

\section{Nonlinear estimation procedure}

Individual rate constants were estimated by using a standard Marquardt-Levenberg least-squares algorithm written in FORTRAN and invoked by the IDL software package. F or analysis of parameter identifiability, the structure of the linearized model in the neighborhood of the computed solution was used, thus yielding the variance-covariance matrix.

\section{Parametric images}

To obtain a parametric image of the unidirectional rate constant $\mathrm{K}$, the Patlak graphic analysis was used on a pixel-by-pixel basis. All frames starting from 20 min until the end of the study were used for a total of eight frames. An average constant time-shift of $12 \mathrm{sec}$ was applied to the arterial blood input function to account for the time-difference between the time-point when activity reaches the brain and the time-point when activity reaches the sampling site. The approach produced a parametric image (47 planes) of the unidirectional rate constant $\mathrm{K}$. Subsequently, all previously 
defined ROIs were copied to these images, and the weighted average over all planes in which the structure appeared was obtained.

\section{Statistical analyses}

Multivariate analysis of variance (MANOVA) was performed to test for gender and left/right differences of regional values of the unidirectional uptake rate constant K. The Friedman test (Siegel and Castellan, 1988) was carried out to determine whether there were significant differences among the regions in average rank of $\mathrm{K}$. The same analysis was used to determine Kendall's coefficient of concordance, which indicates the degree of agreement among the subjects on the rank order of the K values. Further analyses were performed to eval uate the extent to which the rankings of $K$ values across regions were in agreement with the rank order of regional serotonin content in human brain from the literature (Bucht et al., 1981; Cochran et al., 1976; Costa and Aprison, 1958; Mackay et al., 1978). Because the regions could only be partially ordered based on the literature, an adaptation of the J onckheere test $(\mathrm{J}$ onckheere, 1954) using the Ager-Brent partial order statistic (Ager and Brent, 1978) was used. The K value for the brainstem was excluded from this analysis (see Discussion). A linear regression analysis yiel ding the correlation coefficient was performed to relate regional values of $K$ versus regional SUV values. The SD and the coefficient of variation (COV; $100 \% \cdot \mathrm{SD} /$ mean) for individual rate constants were determined directly from the variance-covariance matrix.

\section{RESULTS}

[C-11]AMT accumulated in whole brain for the first 20 min after bolus infusion, after which a plateau was reached and maintained for up to $60 \mathrm{~min}$. Mean brain accumulation for men and women is shown in Figure 2A. The whol ebrain uptake of [C-11]AMT was low, with less than $2 \%$ of the injected dose present in the brain at peak values. [C-11]AMT concentration in whole brain approached the concentration in blood by 40 min after injection (Fig. 2B). The average values for the threecompartment model first-order rate constants for whole brain regions (supratentorial) were determined as $0.0129 / \mathrm{min}$ for $\mathrm{K}_{1}(\mathrm{COV}=13 \%), 0.0292 / \mathrm{min}$ for $\mathrm{K}_{2}$ $(\mathrm{COV}=22 \%)$, and $0.0140 / \mathrm{min}$ for $\mathrm{k}_{3}(\mathrm{COV}=34 \%)$. In general, all parameters were correlated. The correlation coefficient between parameters $k_{2}$ and $k_{3}$ was the highest $(\rho>0.9)$. Nevertheless, for the whole brain region the fitted curve represented the data well (Fig. 3 ), and the analysis of residuals did not reveal any bias. The mean valuefor the metabolic pool $\left(\mathrm{C}_{\mathrm{m}}\right) 50 \mathrm{~min}$ after tracer injection was determined as $40 \%$ of total activity (COV $=10 \%)$ for women and $43 \%$ of total activity $(\mathrm{COV}=12 \%)$ for men (Fig. 3). Different attempts to constrain the parameter values to test whether a
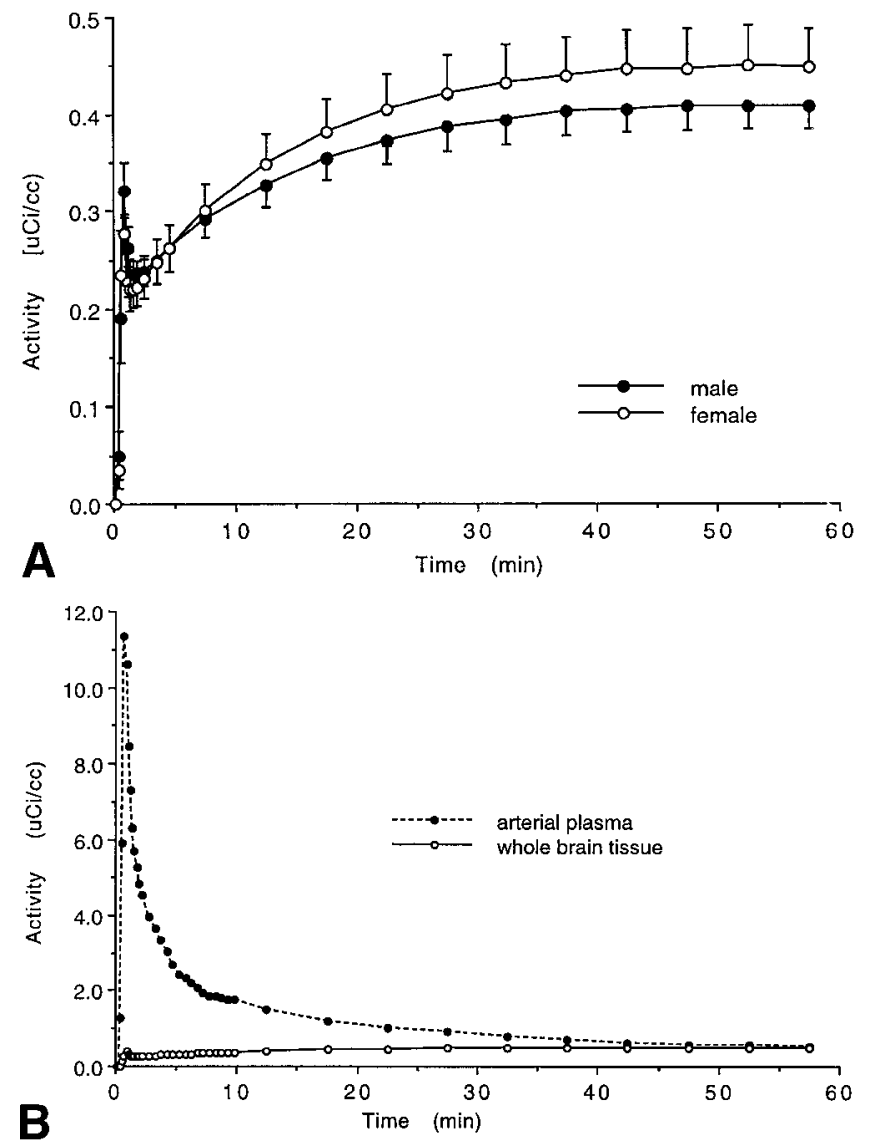

Fig. 2. [C-11]AMT kinetics in plasma and brain. A: [C-11]AMT accumulated in whole brain for the first $20 \mathrm{~min}$ after bolus injection after which a plateau was reached and maintained for up to $60 \mathrm{~min}$. Normalized to unit dose per weight, accumulation was higher in women than in men. B: The whole brain uptake of [C-11]AMT was low, with less than $2 \%$ of the injected dose present in the brain at peak values. [C-11]AMT concentration in brain approached the concentration in blood by 40 min after injection.

smaller contribution of the metabolic pool could be consistent with the data were unsuccessful, as these curves did not fit the data well and clearly showed a bias in the residuals.

The Patlak graphic approach requires dynamic equilibrium of the tracer between the plasma and tissue pools. The computed partition coefficient $C_{f}(t) / C_{p}(t)$ approached a constant value for times greater than 20 min in all brain ROIs, with the exception of the cerebellum (Fig. 4) and white matter (not shown). Therefore, the Patlak analysis was performed by using time frames between 20 and $60 \mathrm{~min}$. A representative Patlak plot for three brain regions (Fig. 5) demonstrates straight lines $(r>0.99)$ with a positive intercept. In those regions that could be fitted, the $K$ value calculated by using the individual rate constants $K_{1}, k_{2}$, and $k_{3}\left(K_{1} k_{3} /\left(k_{2}+k_{3}\right)\right)$ agreed well with values of the unidirectional rate constant $K$ determined by using the Patlak graphic approach, with exception of the cerebel- 


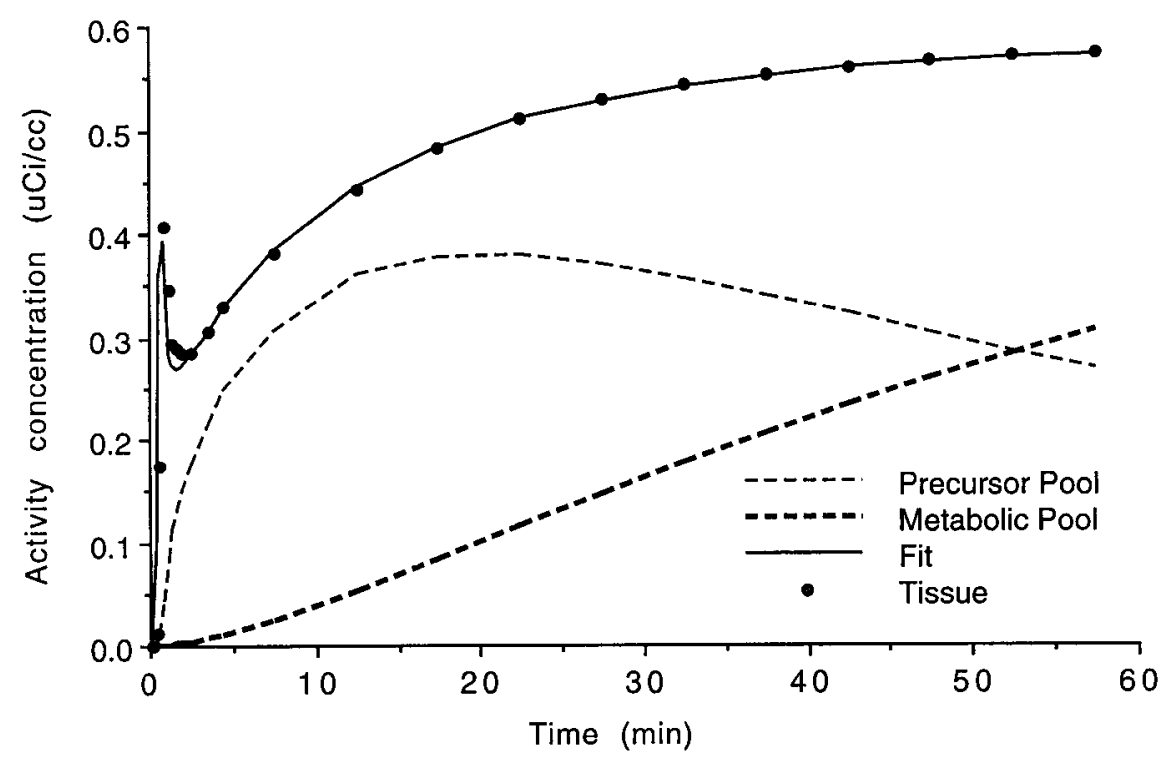

Fig. 3. Three-compartment fit of a time-activity curve representing [C-11]AMT whole brain tissue. Full circles represent actual data points, and the full line indicate the least-squares fit to the data.

Individual rate constants were used to compute contributions from the metabolic pool (thick broken line), the precursor pool (thin broken line), and the blood volume tissue signal (not shown).

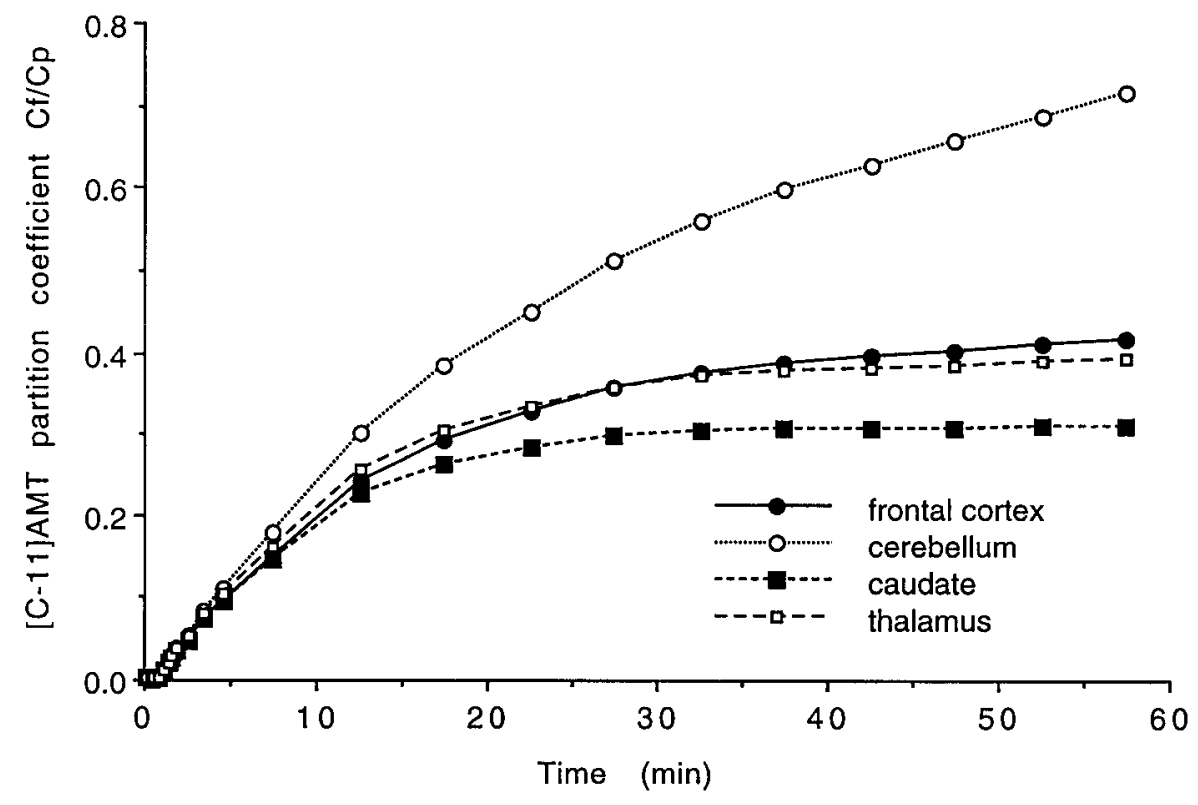

Fig. 4. Relationship between [C-11]AMT partition coefficient and time in a typical normal subject. The quotient between the computed free precursor pool time-activity curve $\mathrm{C}_{\mathrm{f}}(\mathrm{t})$ and the measured plasma time-activity curve $C_{p}(t)$ of [C-11]AMT (which represents the partition

Ium and white matter. The Patlak analysis resulted in overestimation of the unidirectional rate constant in cerebellum and white matter dueto thelack of dynamic equilibrium in these regions during the time of the study.

SUV images were generated by summing data obtained between 30 and $55 \mathrm{~min}$ after injection and revealed widespread distribution of the tracer through- coefficient of [C-11]AMT) is displayed as a function of time and approaches equilibrium for times greater than 20 min in the caudate, frontal cortex, and thalamus but not in the cerebellum.

out brain gray matter (Fig. 6A). ROIs drawn on summed images were used for brain regional analysis of [C11]AMT metabolism. Parametric image analysis of the unidirectional rate constant $\mathrm{K}$ (Fig. 6B) was used to determine regional values for serotonin synthesis capacity (Table II). Regional values for K, obtained by applying ROIs to the parametric images, resulted in stable measurements of $\mathrm{K}$, even for small brain struc- 


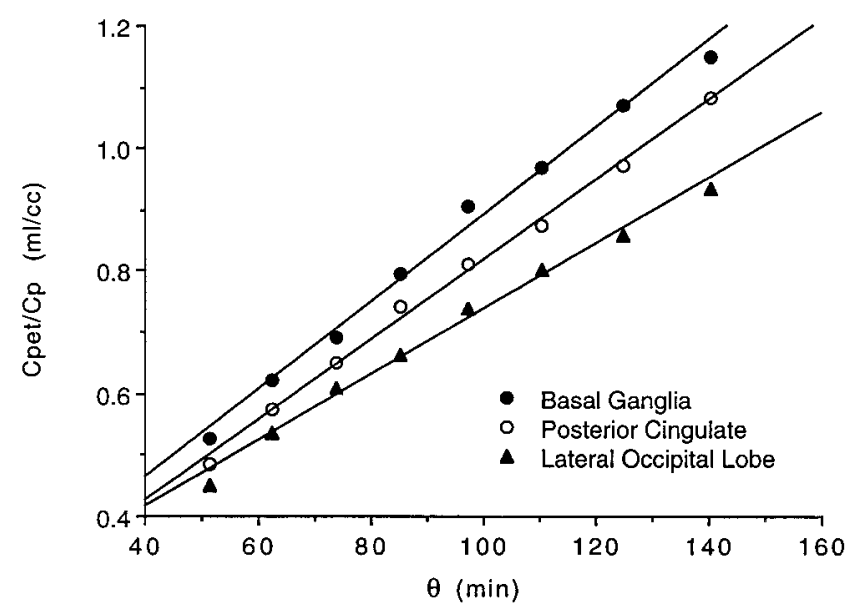

Fig. 5. Patlak graphic analysis of three representative brain regions in one subject. The slope of the regression line equals the rate constant for unidirectional uptake of [C-11]AMT into tissue. $\mathrm{C}_{\mathrm{PET}}$ represents total tissue [C-11] concentration $(\mu \mathrm{Ci} / \mathrm{ml}), \mathrm{C}_{\mathrm{p}}$ denotes [C-11]AMT concentration in plasma $(\mu \mathrm{Ci} / \mathrm{ml})$, and $\theta$ stands for the expression $\left.{ }_{0} \int{ }^{t} C_{p}(u) d u / C_{p}(t)\right)$ in units of minutes. The regression coefficient was higher than 0.99 for all curves.

tures. Regional values for SUV and K were highly correl ated within subjects (Fig. 7).

The rank order of values for the unidirectional uptake rate constant $\mathrm{K}$ corresponded well to the distribution of serotonin content in human brain, with highest values being measured in putamen, caudate, and thalamus. By using Friedman's test, the rank order of regional $\mathrm{K}$ values proved to be highly significant $\left(\right.$ chi $^{2}=127.4$, dof $\left.=19, \mathrm{P}<.0001\right)($ Table III $)$. Furthermore, by using Kendall's coefficient of concordance, the average rank order correlation between pairs of subjects over the regions was $0.634(\mathrm{P}<.0001)$. In addition, by using theAger-Brent statistic, there was highly significant agreement $(P<.0001)$ between the rank order of $\mathrm{K}$ and the a priori partial ordering of regions based on regional serotonin content in human brain from the literature (see Methods for references). Furthermore, regional data values of $\mathrm{K}$ revealed gender differences in serotonin synthesis capacity. Values in women were significantly higher than those measured in men throughout the brain ( $P<.05$, MANOVA) and were particularly higher in the transverse temporal gyrus, anterior cingulate cortex, and cerebellar vermis. There were no statistically significant left/right asymmetries for any of the brain structures measured.

\section{DISCUSSION}

These studies demonstrate the suitability of [C11]AMT as a tracer for PET scanning for determining regional serotonin synthesis capacity in human brain and provide normal adult values for future comparison with patient groups. The calculation of the absolute serotonin synthesis rate requires knowledge of the concentration of tryptophan in blood available for transport into the brain and the LC (the brain/plasma partition coefficients for tryptophan and AMT, as well as the $\mathrm{K}_{\mathrm{m}}$ and $\mathrm{V}_{\max }$ of these substrates for tryptophan hydroxylase). Although the LC for [C-11]AMT has been measured in rats (Vanier et al., 1995) and in rhesus monkeys (Shoaf and Schmall, 1996), it has not yet been measured in humans. However, the LC is a constant for the species and represents a mere scaling factor, which does not affect differences among subjects. Furthermore, there is considerable controversy in the literature regarding the fraction of tryptophan in blood available for transport into the brain (see Theory). We have attempted to minimize variability in plasma tryptophan by fasting all subjects for $12 \mathrm{~h}$ before the PET scan and performing all studies at the same time of the day (between 2 and 4 P.M.). Due to the standardized conditions of our study protocol, there was little variability in the plasma tryptophan concentration. Under these conditions, the uni directional uptake rate constant $K$ is the main predictor of serotonin synthesis rate, and it is the only variable that reflects any dynamic information obtained by the tracer kinetic model. In addition, within a subject, differences in serotonin synthesis rate between brain structures are directly related to K, as the two other factors are common scaling factors for all regions. Thus, any rank order obtained from measure ment of $K$ is strictly valid for the serotonin synthesis rate.

Furthermore, we obtained an excellent correlation between regional values of $\mathrm{K}$ and regional SUVs. This indicates that differences in tracer uptake in different brain structures are mainly due to the unidirectional uptake and metabolism of [C-11]AMT to [C-11]AM5HT. It also suggests that the free precursor pool is homogeneous over brain structures and further supports our findings that the metabolic pool is of the same order as the free precursor pool and thus can be distinctly measured against the background of the free precursor pool.

Although there is low uptake of the tracer in the brain relative to other compounds commonly used for PET imaging, variability of regional values among normal subjects (Table II) is similar to those reported for other tracers (e.g., COV reported by Holthoff et al. [1991] ranged between 5 and 21\% for [C-11]flumazenil). Importantly, rank order of regional brain values for $\mathrm{K}$ is consistent with the rank order for serotonin content in human brain. Although the highest concentrations of serotonin and various measures of innervation density measured in vitro are localized to serotonergic cell bodies in the brainstem nuclei, the brainstem was not among the regions with high $\mathrm{K}$ values in the present study. This finding is not unexpected, however, due to the limits of the spatial resolution of PET technology (reconstructed image in-plane resolution obtained is $5.5 \pm 0.35 \mathrm{~mm}$ at $\mathrm{FWHM}$ and $6.0 \pm 0.49 \mathrm{~mm}$ in the 
A
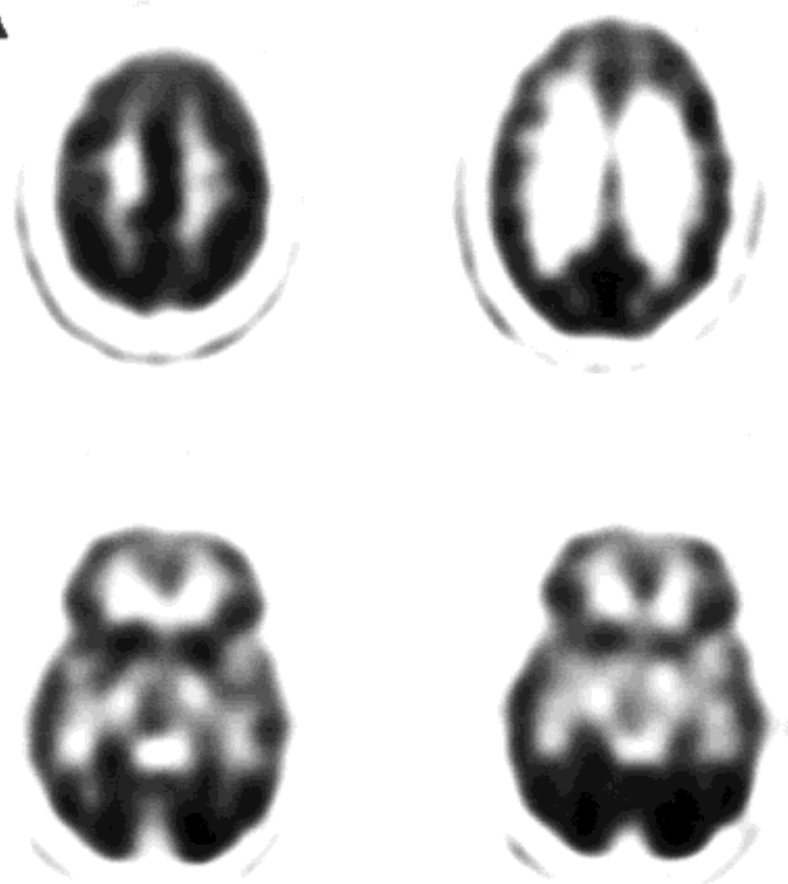

B
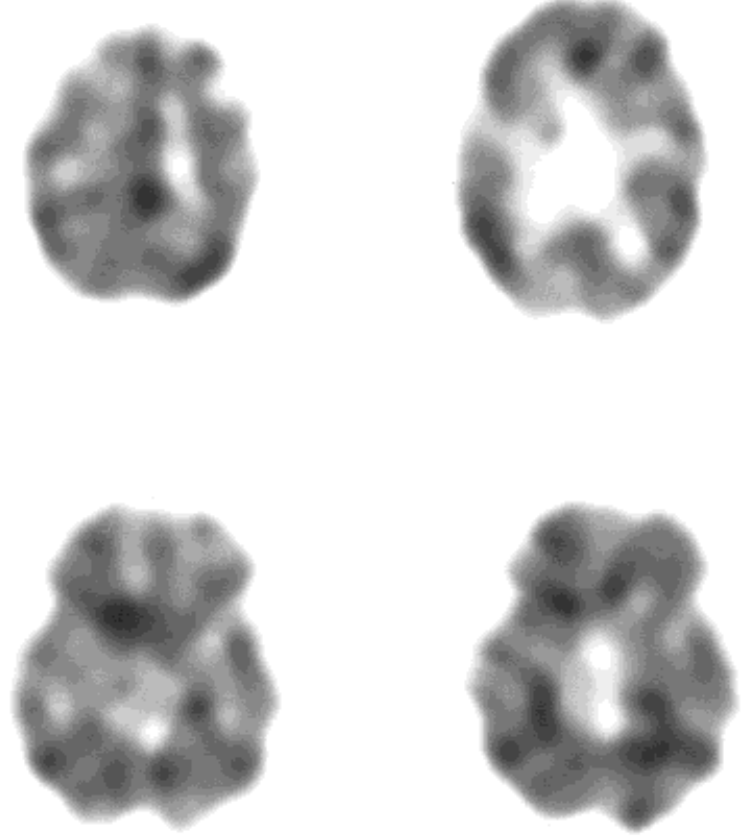

Fig. 6. A: [C-11]AMT distribution in normal adult brain. Transaxial brain images at eight levels generated by summing data obtained between 30 and 55 min after injection revealed widespread

axial direction) compared with the small size of the nuclei containing the several thousand serotonergic cell bodies located near the midl ine of the brainstem (Tork, 1990; Tork and Hornung, 1990), as well as the problem of partial volume in very small structures (Hoffman et al., 1979). The rank order of $K$ values for the remaining
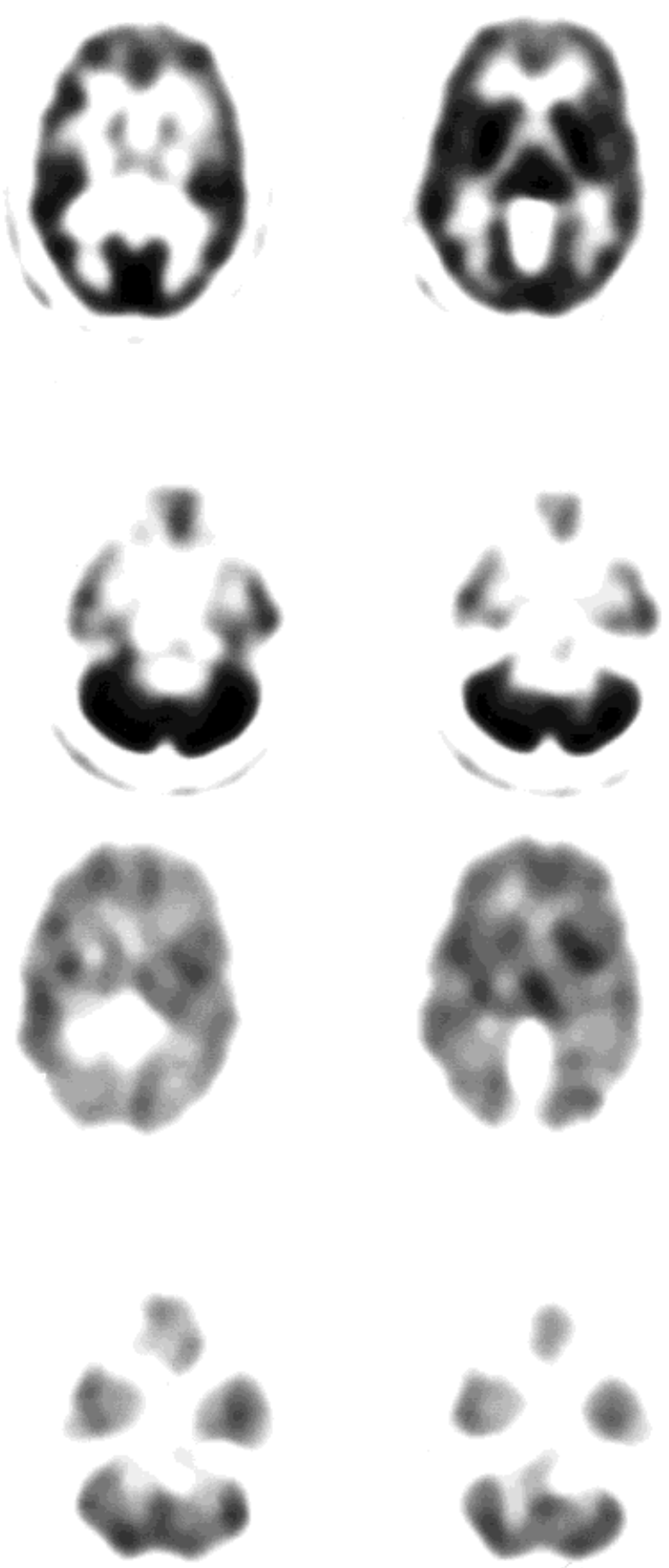

distribution of the tracer throughout brain gray matter. B: Parametric images of the unidirectional uptake rate constant $\mathrm{K}$ in normal adult brain. Parametric images of the same brain levels shown in A.

brain regions in the present study shows a statistically significant correlation with the rank order of serotonin content in human brain. The highest values for serotonin synthesis capacity were found in putamen, caudate, thalamus, and hippocampus. Among cortical regions, limbic areas such as rectal gyrus, anterior cingulate 
TABLE II. Brain regional values of serotonin synthesis capacity (uptake rate constant $\mathrm{K})^{1}$

\begin{tabular}{|c|c|c|c|c|c|c|}
\hline \multirow[b]{3}{*}{ Brain region } & \multicolumn{2}{|c|}{$\begin{array}{l}\text { All subjects } \\
(\mathrm{N}=10)\end{array}$} & \multicolumn{2}{|c|}{$\begin{array}{l}\text { Males } \\
(\mathrm{N}=5)\end{array}$} & \multicolumn{2}{|c|}{$\begin{array}{l}\text { Female } \\
(\mathrm{N}=5)\end{array}$} \\
\hline & $\mathrm{K}$ & COV & $\mathrm{K}$ & COV & $\mathrm{K}$ & $\mathrm{cov}$ \\
\hline & \multicolumn{2}{|c|}{$\begin{array}{c}(\mathrm{ml} / \mathrm{g} / \mathrm{min}) \times \\
10^{-3}\end{array}$} & \multicolumn{2}{|c|}{$\begin{array}{c}(\mathrm{ml} / \mathrm{g} / \mathrm{min}) \times \\
10^{-3}\end{array}$} & \multicolumn{2}{|c|}{$\begin{array}{c}(\mathrm{ml} / \mathrm{g} / \mathrm{min}) \\
10^{-3}\end{array}$} \\
\hline \multicolumn{7}{|c|}{$\begin{array}{l}\text { Whole brain (Supratento- } \\
\text { rial) }\end{array}$} \\
\hline $\begin{array}{l}(\mathrm{R}) \\
(\mathrm{L})\end{array}$ & $\begin{array}{l}5.02 \\
5.02\end{array}$ & $\begin{array}{l}10 \\
10\end{array}$ & $\begin{array}{l}4.73 \\
4.73\end{array}$ & $\begin{array}{l}11 \\
11\end{array}$ & $\begin{array}{l}5.32 \\
5.32\end{array}$ & $\begin{array}{l}6 \\
5\end{array}$ \\
\hline \multicolumn{7}{|l|}{ Frontal lobe } \\
\hline $\begin{array}{l}\text { Frontal cortex } \\
\text { (R) } \\
\text { (L) }\end{array}$ & $\begin{array}{l}4.89 \\
4.93\end{array}$ & $\begin{array}{l}12 \\
11\end{array}$ & $\begin{array}{l}4.57 \\
4.68\end{array}$ & $\begin{array}{l}14 \\
13\end{array}$ & $\begin{array}{l}5.20 \\
5.17\end{array}$ & $\begin{array}{l}5 \\
5\end{array}$ \\
\hline $\begin{array}{l}\text { Rectal gyrus } \\
\text { (R) } \\
\text { (L) }\end{array}$ & $\begin{array}{l}5.94 \\
5.78\end{array}$ & $\begin{array}{l}13 \\
17\end{array}$ & $\begin{array}{l}6.29 \\
5.99\end{array}$ & $\begin{array}{l}15 \\
22\end{array}$ & $\begin{array}{l}5.51 \\
5.52\end{array}$ & $\begin{array}{l}5 \\
7\end{array}$ \\
\hline \multicolumn{7}{|l|}{ Temporal lobe } \\
\hline $\begin{array}{l}\text { Transverse } \\
\text { (R) } \\
\text { (L) }\end{array}$ & $\begin{array}{l}5.66 \\
5.76\end{array}$ & $\begin{array}{l}14 \\
12\end{array}$ & $\begin{array}{l}5.21 \\
5.42\end{array}$ & $\begin{array}{l}12 \\
15\end{array}$ & $\begin{array}{l}6.11 \\
6.10\end{array}$ & $\begin{array}{r}11 \\
6\end{array}$ \\
\hline \multicolumn{7}{|l|}{ Superior } \\
\hline (L) & 5.03 & 10 & 4.82 & 12 & 5.23 & 7 \\
\hline $\begin{array}{l}\text { Middle } \\
\text { (R) } \\
\text { (L) }\end{array}$ & $\begin{array}{l}5.12 \\
5.17\end{array}$ & $\begin{array}{r}9 \\
12\end{array}$ & $\begin{array}{l}4.89 \\
5.01\end{array}$ & $\begin{array}{r}9 \\
13\end{array}$ & $\begin{array}{l}5.41 \\
5.36\end{array}$ & $\begin{array}{r}7 \\
10\end{array}$ \\
\hline \multicolumn{7}{|l|}{ Inferior } \\
\hline $\begin{array}{l}\text { (R) } \\
(\mathrm{L})\end{array}$ & $\begin{array}{l}5.00 \\
4.93\end{array}$ & $\begin{array}{l}10 \\
12\end{array}$ & $\begin{array}{l}4.87 \\
4.76\end{array}$ & $\begin{array}{l}14 \\
13\end{array}$ & $\begin{array}{l}5.13 \\
5.14\end{array}$ & $\begin{array}{r}5 \\
10\end{array}$ \\
\hline \multicolumn{7}{|l|}{ Hippocampus } \\
\hline $\begin{array}{l}(\mathrm{R}) \\
(\mathrm{L})\end{array}$ & $\begin{array}{l}5.15 \\
5.31\end{array}$ & $\begin{array}{l}13 \\
21\end{array}$ & $\begin{array}{l}4.88 \\
4.77\end{array}$ & $\begin{array}{l}10 \\
14\end{array}$ & $\begin{array}{l}5.50 \\
6.04\end{array}$ & $\begin{array}{l}14 \\
21\end{array}$ \\
\hline \multicolumn{7}{|l|}{ Other cortical regions } \\
\hline \multicolumn{7}{|l|}{ Parietal cortex } \\
\hline $\begin{array}{l}\text { (R) } \\
(\mathrm{L})\end{array}$ & 4.80 & 9 & 4.60 & 9 & 5.00 & $\begin{array}{l}7 \\
8\end{array}$ \\
\hline \multicolumn{7}{|l|}{ Occip. cortex } \\
\hline (R) & 4.83 & 9 & 4.71 & 11 & 4.95 & 8 \\
\hline \multicolumn{6}{|l|}{ Anterior cingulate } & \\
\hline $\begin{array}{l}\text { (R) } \\
\text { (L) }\end{array}$ & $\begin{array}{l}5.57 \\
5.66\end{array}$ & $\begin{array}{l}11 \\
11\end{array}$ & $\begin{array}{l}5.17 \\
5.36\end{array}$ & $\begin{array}{r}9 \\
13\end{array}$ & $\begin{array}{l}5.00 \\
5.96\end{array}$ & $\begin{array}{l}8 \\
5\end{array}$ \\
\hline \multicolumn{7}{|l|}{ Posterior cingulate } \\
\hline $\begin{array}{l}(\mathrm{R}) \\
(\mathrm{L})\end{array}$ & $\begin{array}{l}5.32 \\
5.48\end{array}$ & $\begin{array}{l}9 \\
8\end{array}$ & $\begin{array}{l}5.18 \\
5.42\end{array}$ & $\begin{array}{r}11 \\
9\end{array}$ & $\begin{array}{l}5.46 \\
5.54\end{array}$ & $\begin{array}{l}7 \\
6\end{array}$ \\
\hline \multicolumn{7}{|l|}{ Subcortical structures } \\
\hline $\begin{array}{l}\text { Caudate nucleus } \\
\text { (R) } \\
\text { (L) }\end{array}$ & $\begin{array}{l}5.90 \\
5.68\end{array}$ & $\begin{array}{l}14 \\
13\end{array}$ & $\begin{array}{l}5.69 \\
5.21\end{array}$ & $\begin{array}{l}19 \\
11\end{array}$ & $\begin{array}{l}6.11 \\
6.16\end{array}$ & $\begin{array}{l}9 \\
8\end{array}$ \\
\hline \multicolumn{7}{|l|}{ Putamen } \\
\hline $\begin{array}{l}\text { (R) } \\
(\mathrm{L})\end{array}$ & $\begin{array}{l}6.37 \\
6.18\end{array}$ & $\begin{array}{l}8 \\
9\end{array}$ & $\begin{array}{l}6.10 \\
5.86\end{array}$ & $\begin{array}{r}8 \\
10\end{array}$ & $\begin{array}{l}6.64 \\
6.50\end{array}$ & $\begin{array}{l}6 \\
5\end{array}$ \\
\hline \multicolumn{7}{|l|}{ Thalamus } \\
\hline $\begin{array}{l}(\mathrm{R}) \\
(\mathrm{L})\end{array}$ & $\begin{array}{l}5.70 \\
5.66\end{array}$ & $\begin{array}{l}13 \\
14\end{array}$ & $\begin{array}{l}5.41 \\
5.27\end{array}$ & $\begin{array}{l}15 \\
16\end{array}$ & $\begin{array}{l}5.98 \\
6.06\end{array}$ & $\begin{array}{l}9 \\
9\end{array}$ \\
\hline Brainstem & 4.94 & 13 & 4.84 & 17 & 5.06 & 9 \\
\hline Cerebellum & & & & & & \\
\hline $\begin{array}{l}\text { Hemispheres } \\
\text { (R) }\end{array}$ & & & & & & \\
\hline (L) & $\begin{array}{l}3.35 \\
5.45\end{array}$ & 10 & 5.28 & 12 & $\begin{array}{l}5.19 \\
5.67\end{array}$ & 6 \\
\hline Vermis & 5.69 & 13 & 5.24 & 8 & 6.26 & 11 \\
\hline $\begin{array}{l}\text { White matt } \\
\text { Centrum }\end{array}$ & & & & & & \\
\hline Centr & 2.54 & 9 & 2.32 & 4 & .83 & 3 \\
\hline
\end{tabular}

${ }_{1}$ Mean and percentage coefficient of variation ( $\mathrm{COV}=100 \% \times \mathrm{SD} /$ mean) of $\mathrm{K}$ complex are reported. ( $\mathrm{R}=$ right, $\mathrm{L}=$ left).

gyrus, and transverse temporal gyrus demonstrated higher rates of serotonin synthesis than other regions of the cortex. Serotonin content (Bucht et al., 1981; Cochran et al., 1976; Costa and Aprison, 1958; Mackay et al., 1978) and serotonin uptake carrier studies in human brain (Cortes et al., 1988; Laruelle et al., 1988)

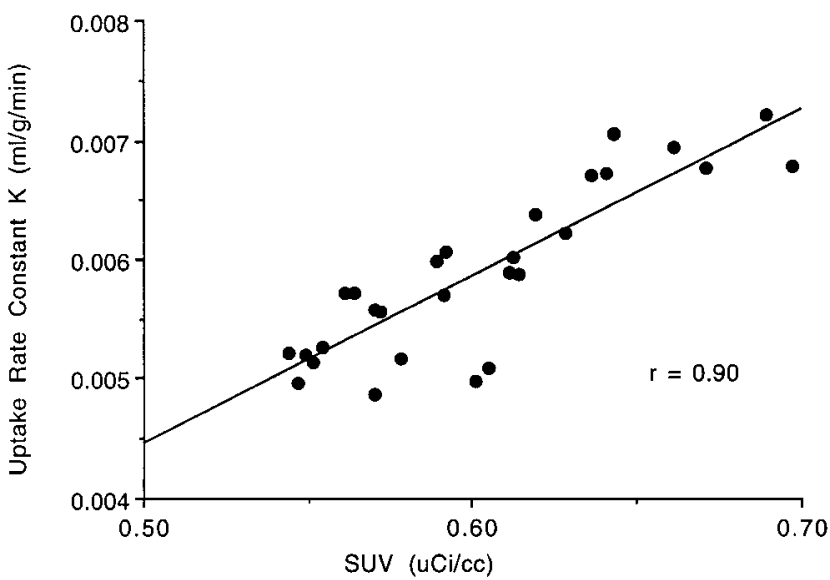

Fig. 7. Unidirectional uptake rate constant $\mathrm{K}$ of [C-11]AMT into tissue as a function of the standardized uptake value (SUV). The SUV represents total accumulation of tracer into tissue normalized to the injected activity and patient weight. Each point represents a specific brain region in one representative subject. The correlation coefficient is $0.90(\mathrm{P}<.05)$.

TABLE III. Rank order of 20 brain regional values of serotonin synthesis capacity ${ }^{1}$

\begin{tabular}{|c|c|}
\hline Brain region & $\begin{array}{c}\text { Mean } \\
\text { rank }\end{array}$ \\
\hline Putamen & 19.7 \\
\hline Caudate nucleus & 16.7 \\
\hline Transverse temporal gyrus & 15.7 \\
\hline Thalamus & 15.25 \\
\hline Anterior cingulate gyrus & 14.75 \\
\hline Cerebellar hemispheres & 14.65 \\
\hline Cerebellar vermis & 13.8 \\
\hline Posterior cingulate gyrus & 12.9 \\
\hline Hippocampus & 12.0 \\
\hline Rectal gyrus & 11.15 \\
\hline Middle temporal gyrus & 9.75 \\
\hline Retrosplenial cingulate & 7.75 \\
\hline Whole brain & 7.7 \\
\hline Brainstem & 7.35 \\
\hline Inferior temporal gyrus & 7.15 \\
\hline Superior temporal gyrus & 6.95 \\
\hline Frontal cortex & 5.5 \\
\hline Primary occipital cortex & 5.1 \\
\hline Parietal cortex & 4.55 \\
\hline Lateral occipital cortex & 1.6 \\
\hline
\end{tabular}
capacity.

show that the values for cerebellum are very similar to those measured in cerebral cortex. In the present study, values of the unidirectional rate constant $K$ for the cerebel lum were determined to be higher than those in the cerebral cortex and hippocampus. However, because dynamic equilibrium is not approached in the cerebel lum during the study, the Patlak graphic analysis is not valid in this brain region. The reason for the apparently longer half-life of the free precursor pool in the cerebel lum as compared with other brain structures is unclear and warrants further investigation.

In addition to metabolism by tryptophan hydroxylase, tryptophan is metabolized by tryptophan 2,3dioxygenase (Haber et al., 1993) and indoleamine 2,3- 
di oxygenase (Yamazaki et al., 1985) via the kynurenine pathway in the brain. Under normal circumstances, however, the metabolites of these pathways are between 100- and 1,000-fol d lower than the concentration of tryptophan in the brain (Saito et al., 1993). By comparison, the sum of the concentrations of serotonin and its metabolite 5-hydroxyindole acetic acid is approximately one-fifth the concentration of tryptophan in brain (Hery et al., 1977). Therefore, the kynurenine pathways are not expected to confound the interpretation of data in the present study. However, after ischemic brain injury or immune activation, induction of indoleamine 2,3-dioxygenase can result in a 10-fold increase in quinolinic acid in brain (Saito et al., 1993), and therefore, under these circumstances this pathway should be considered.

The gender differences in brain serotonin synthesis observed in the present study are consistent with reports in the literature of small but significantly higher serotonin content (Carlsson et al., 1985; Kato, 1960; Rosencrans, 1970), higher 5-hydroxytryptophan accumulation after inhibition of aromatic amino acid decarboxylase (Carlsson et al., 1985; Watts and Stanley, 1984), and higher serotonin accumulation after monoamine oxidase inhibition (Carlsson et al., 1985; Rosecrans, 1970) in female rats than in male rats. Further, the differences between male and female rats persisted after treatment with tryptophan, which produced brain concentrations of tryptophan that saturated tryptophan hydroxylase, demonstrating that the gender differences in serotonin synthesis capacity were independent of plasma tryptophan concentration (Carlsson and Carlsson, 1988). Young et al. (1980) reported significantly higher 5-HIAA in cerebrospinal fluid in women than in men, suggesting a higher rate of serotonin metabolism for women. Differences in the serotonin synthesis between men and women may reflect gender differences of importance to both normal and pathologic behavior.

\section{ACKNOWLEDGMENTS}

We are indebted to Dr. Mirko Diksic and Dr. Robert Koeppe for many hel pful discussions concerning these studies, to Dr. J oel Ager and Mr. J ames J anisse for performing statistical analyses, to Dr. J ohn Ofenstein for plasma tryptophan measurements, and to the staff of the Children's Hospital of Michigan PET Center for their endurance. These studies were supported in part by the Mental IIIness Research Association (MIRA) of Michigan, to which we are grateful.

\section{REFERENCES}

Ager, J .W., J r., and Brent, S.B. (1978) An index of agreement between hypothesized partial order and an empirical rank order. J. Am. Statistical Assoc., 73:827-830.

Bergström, M., Litton, J ., Eriksson, L., et al. (1982) Determination of object contour from projections for attenuation correction in cranial positron emission tomography. J Comput. Assist. Tomogr., 6:365372.

Bloxam, D.L., and Curzon, G. (1978) A study of proposed determinants of brain tryptophan concentration in rats after portocaval anastomosis or sham operation. J. Neurochem., 31:1255-1263.

Bloxam, D.L., Tricklebank, M.D., Patel, A.J ., and Curzon, G. (1980) Effects of albumin, amino acids, and clofibrate on the uptake of tryptophan by the rat brain. J. Neurochem., 34:43-49.

Bucht, G., Adolfsson, R., Gottfries, C.G., Roos, B.-E., and Winblad, B. (1981) Distribution of 5-hydroxytryptamineand 5-hydroxyindoleacetic acid in human brain in relation to age, drug influence, agonal status and circadian variation. . . Neural Transm., 51:185-203.

Carlsson, M., and Carlsson, A. (1988) In vivo evidence for a greater brain tryptophan hydroxylase capacity in female than in male rats. Naunyn Schmiedebergs Arch. Pharmacol., 338:345-349.

Carlsson, M., Svensson, K., Eriksson, E., and Carlsson, A. (1985) Rat brain serotonin: biochemical and functional evidence for a sex difference. J . Neural Transm., 63:297-313.

Chakraborty, P.K., Mangner, T.J ., Chugani, D.C., et al. (1996) A high-yield and simplified procedurefor the synthesis of $\alpha\left[{ }^{[11} \mathrm{C}\right]$ methylL-tryptophan. Nucl. Med. Biol., 23:1005-1008.

Cochran, E., Robins, E., and Grote, S. (1976) Regional serotonin levels in brain. A comparison of depressive suicides and alcoholic suicides with controls. Biol. Psychiatry, 11:283-294.

Cohen, Z., Tsuiki, K., Takada, A., et al. (1995) In vivo-synthesized radioactively labelled $\alpha$-methyl serotonin as a selective tracer for visualization of brain serotonin neurons. Synapse, 21:21-28.

Cortes, R., Soriano, E., Pazos, A., Probst, A., and Palacios, J.M. (1988) Autoradiography of antidepressant binding sites in the human brain: localization using $\left[{ }^{3} \mathrm{H}\right]$ imi pramineand $\left[{ }^{3} \mathrm{H}\right.$ ]paroxetine. Neuroscience 27:473-496.

Costa, E., and Aprison, M.H. (1958) Studies on the 5-hydroxytryptamine (serotonin) content in human brain. J. Nerv. Ment. Dis., 126:289-293.

Diksic, M., Nagahiro, S., Sourkes, T.L., and Yamamoto, Y.L. (1990) A new method to measure brain serotonin synthesis in vivo. I. Theory and basic data for a biological model. J . Cereb. Blood Flow M etab. 9:1-12.

Diksic, M., Nagahiro, S., Chaly, T., et al. (1991) Serotonin synthesis rate measured in living dog brain by positron emission tomography. J . Neurochem., 56:153-162.

Fernstrom, J .D., and Wurtman, R.J . (1972) Brain serotonin content: physiological regulation by plasma neutral amino acids. Science 178:414-416

Fernstrom, J.D., Larin, F., and Wurtman, R.J . (1973) Correlations between brain tryptophan and plasma neutral amino acid levels following food consumption in rats. Life Sci., 13:517-524.

Gessa, G.L., and Tagliamonte, A. (1974) Possible role of free serum tryptophan in the control of brain tryptophan level and serotonin synthesis. Adv. Biochem. Psychopharmacol. 11:119-131.

Gupta, N.C., Frank, A.R., Dewan, N.A., et al. (1992) Solitary pulmonary nodules: detection of malignancy with PET with 2-[F-18]-fluoro2-deoxy-D-glucose. Radiology, 184:441-444.

Haber, R., Bessette, D., Hulihan-Giblin, B., et al. (1993) I dentification of tryptophan 2,3-dioxygenase RNA in rodent brain. J . Neurochem., 60:1159-1162

Hery, F., Chouvet, G., Kan, J .P., et al. (1977) Daily variations of various parameters of serotonin metabolism in the rat brain. II. Circadian variations in serum and cerebral tryptophan levels: lack of correlations with 5-HT turnover. Brain Res., 123:137-145.

Hoffman, E.J ., Huang, S.C., and Phelps, M.E. (1979) Quantitation in positron emission computed tomography: 1 . Effect of object size. J . Comput. Assist. Tomogr., 3:299-308.

Holthoff, V.A. Koeppe, R.A., Frey, K.A., et al. (1991) Differentiation of radioligand delivery and binding in the brain: validation of a two-compartment model for $\left.{ }^{[11} \mathrm{C}\right]$ flumazenil. J . Cereb. Blood Flow Metab., 11:745-752.

Hoyer, D., Clarke, D.E., F ozard, J .R., et al. (1994) VII. International Union of Pharmacology classification of receptors for 5-hydroxytryptamine (serotonin). Pharm. Rev., 46:157-203.

IRCP Publication 53. (1988) Radiation doseto patients from radiopharmaceutical. In: Annals of the International Commission on Radiol ogical Protection. Pergamon Press, New York, p. 15.

J acobs, B.L., and Azmitia, E.C. (1992) Structure and function of the brain serotonin system. Physiol. Rev., 72:165-229.

J onckheere, A.R. (1954) A test of significance for the relation between $\mathrm{M}$ ranks and $\mathrm{K}$ ranked categories. Br. J. Statistical Psychology, 7:93-100.

Kato, R. (1960) Serotonin content of rat brain in relation to sex and age. J . Neurochem., 5:202.

Kenney, J.M., Marinelli, L.D., and Woodard, H.Q. (1941) Tracer 
studies with radioactive phosphorus in malignant neoplastic disease. Radiology, 37:683-690.

Knott, P.J ., and Curzon, G. (1972) Free tryptophan in plasma and brain tryptophan metabolism. Nature, 239:452-453.

Krstulovic, A.M., and Matsura, C. (1979) Rapid analysis of tryptophan metabolites using reversed-phase high-performance chromatography with fluorometric detection. J . Chromatogr., 163:72-76.

Laruelle, M., Vanisberg, M.-A., and Maloteaux, J .-M. (1988) Regional and subcellular localization in human brain of $\left[{ }^{3} \mathrm{H}\right]$ paroxetine binding, a marker of serotonin uptake sites. Biol. Psychiatry, 24:299-309.

Mackay, A.V.P., Yates, C.M., Wright, A., Hamilton, P., and Davies, P. (1978) Regional distribution of monoamines and their metabolites in the human brain. J . Neurochem., 30:841-848.

Madras, B.K., and Sourkes, T.L. (1965) Metabolism of $\alpha$-methyltryptophan. Biochem. Pharmacol., 14:1499-1506.

Madras, B.K., Cohen, E.L., Fernstrom, J.D., et al. (1973) Dietary carbohydrate increases brain tryptophan and decreases serum-free tryptophan. Nature, 244:34-35.

Madras, B.K., Cohen, E.L., Messing, R.B., et al. (1974) Relevance of free tryptophan in serum to tissue tryptophan concentrations. Metabolism, 23:1107-1116.

Minderaa, R.B., Anderson, G.M., Volkmar, F.R., Akkerhuis, G.W., and Cohen, D.J . (1987) Urinary 5-hydroxyindoleacetic acid and whole blood serotonin and tryptophan in autistic and normal subjects. Biol. Psychiatry, 22:933-940.

Missala, K., and Sourkes, T.L. (1988) Functional cerebral activity of an anal ogue of serotonin formed in situ. Neurochem. Int., 12:209-214.

Murphy, D.L. (1990) Neuropsychiatric disorders and the multiple human brain serotonin receptor subtypes and subsystems. N europsychopharmacology, 3:457-471.

Muzik, O., Chugani, D.C., Chakraborty, P., Mangner, T., and Chugani, H.T. (1997) Analysis of [C-11]al pha-methyl-tryptophan kinetics for the estimation of serotonin synthesis rate in vivo. J . Cereb. Blood Flow Metab. 17:659-669.

Pardridge, W.M. (1979) Tryptophan transport through the blood-brain barrier: in vivo measurement of free and al bumin-bound amino acid. Life Sci., 25:1519-1528.

Pardridge, W.M., and Fierer, G. (1990) Transport of tryptophan into brain from the circulating, albumin-bound pool in rats and in rabbits. J . Neurochem., 54:971-976.

Patlak, C.S., Blasberg, R.G., and Fenstermacher, J D. (1983) Graphical evaluation of blood-to-brain transfer constants from multiple time uptake data. J. Cereb. Blood Flow Metab., 3:1-7.

Peroutka, S.J . (1994) 5-Hydroxytryptamine receptors in vertebrates and invertebrates: why arethere so many? Neurochem. Int., 25:533536.
Rosencrans, J .A. (1970) Differences in brain area 5-hydroxytryptamine turnover and rearing behavior in rats and mice of both sexes. Eur. J . Pharmacol., 9:379-382.

Roth, B.L. (1994) Multiple serotonin receptors: clinical and experimental aspects. Ann. Clin. Psychiatry, 6:67-78.

Saito, K., Nowak, T.S., J r., Suyama, K., et al. (1993) Kynurenine pathway enzymes in brain: responses to ischemic brain injury versus systemic immune activation. J . Neurochem., 61:2061-2070.

Shoaf, S.E., and Schmall, B. (1996) Pharmacokinetics of $\alpha$-methyl-Ltryptophan in rhesus monkeys and calculation of the lumped constant for estimating the rate of serotonin synthesis. J . Pharmacol. Exp. Ther., 277:219-224.

Siegel, S., and Castellan, N.J ., J r. (1988) Nonparametric Statistics for the Behavioural Sciences. McGraw-Hill, New York.

Sokol off, L., Reivich, M., Kennedy, C., et al. (1977) The $\left[{ }^{14} \mathrm{C}\right]$ deoxyglucose method for the measurement of local cerebral glucose utilization: theory, procedure, and normal values in the conscieous and anaesthetized al bino rat. J . Neurochem., 28:897-916.

Sourkes, T.L. (1971) Alpha-methyltryptophan and its actions on tryptophan metabolism. Fed. Proc., 30:897-903.

Strauss, L.G., and Conti, P.S. (1991) Theapplications of PET in clinical oncology. J. Nuclear Med., 32:623-647.

Tork, I. (1990) Anatomy of the serotonergic system. Ann. N.Y. Acad. Sci., 600:9-35.

Tork, I., and Hornung, J.-P. (1990) Raphe nuclei and serotonin containing systems. In: The Human Nervous System. G. Paxinos, ed. Academic Press, San Diego, CA, pp. 1001-1022.

Vanier, M., Tsuiki, K., Grdisa, M., Worsley, K., and Diksic, M. (1995) Determination of the lumped constant for the $\alpha$-methyltryptophan method of estimating the rate of serotonin synthesis. J . Neurochem., 64:624-635.

Watts, A.G., and Stanley, H.F. (1984) Indoleamines in the hypothalamus and area of the midbrain raphe nuclei of male and female rats throughout postnatal development. Neuroendocrinology, 38:461466.

Woodard, H.Q., Gigler, R.E., Freed, B., and Russ, G. (1975) Expression of tissue isotope distribution. J. Nucl. Med. 16:958-959.

Yamazaki, F., Kuroiwa, T., Takikawa, O., and Kido, R. (1985) Human indoleamine 2,3-dioxygenase. Biochem. I ., 230:635-638.

Young, S.N., Gauthier, S., Anderson, G.M., and Purdy, W.C. (1980) Tryptophan, 5-hydroxyindoleacetic acid and indoleacetic acid in human cerebrospinal fluid: interrelationships and the influence of age, sex, epilepsy and antoconvulsant drugs. J . Neurol. Neurosurg. Psychiatry, 43:438-445.

Yuwiler, A., Oldendorf, W.H., Geller, E., and Braun, L. (1977) Effect of al bumin binding and amino acid competition on tryptophan uptake into brain. J . Neurochem., 28:1015-1023. 